\title{
Crisis, States \\ and the Sociology of Southeast Asia: \\ Constructing and Deconstructing 1997
}

\author{
JOHN CLAMMER
}

\begin{abstract}
The events of 1997 in Southeast Asia have been largely interpreted as a financial crisis, as a momentary problem in an otherwise smoothly operating development model. This paper takes issue with this interpretation and argues that in fact it indicated the extent of the penetration of globalization in the region and threw into stark relief the underlying sociological transformations that have accompanied and been created by the developmentalist policies of regional states. The paper attempts to indicate what the major sociological issues generated by the crisis are, to argue for the continuing salience of class analysis in interpreting social transformations in contemporary Southeast Asia and to propose the elements of a fresh sociological model for examining post-crisis Southeast Asian societies encapsulated in a pattern of globalization that is having profound but not yet fully mapped cultural and social consequences. The paper in other words attempts a sociological interpretation of what has been mostly read as an economic problem, and indicates necessary linkages between the economic, the sociological and the cultural in the interpretation of social change in the region.
\end{abstract}

\section{Theorizing 1997}

Prior to 1997 the non-socialist societies of Southeast Asia were, with the exception of Myanmar (Burma), widely held up as examples of the success of 'development' understood in its conventional sense as economic growth accompanied by some level of poverty alleviation, urbanization and the expansion of infrastructure, both physical (roads, bridges, airports) and social (in particular education and medical care). Many scholars have argued that, despite the human and ecological costs of such development and its disruption of sociological and cultural patterns and more traditional ways of life, on the whole the balance sheet is positive and that compared with the experiences of many societies in Latin America and Africa, Southeast Asia is a success story (Rigg 1997; Maidment and Mackerras 1998). 
In 1997 however, began the worst economic crisis in postwar Southeast Asian history. While a number of commentators have examined the massive social fallout of this crisis and its political implications in terms of what it might say about the states of the region, their real political autonomy in the world system, local political cultures and the possibilities of more genuine democratization (Acharya 1998; Johannen, Rudolph and Gomez 2000), for the most part it has been largely interpreted as a failure of regulatory policies and institutions, and to a lesser extent of the political systems managing these institutions (Arndt and Hall 1999). It has in fact been almost exclusively read and presented as a financial crisis, as a technical problem in the smooth running of the international capitalist system, and a whole literature has emerged presenting the massive economic disarray as a 'problem' of capital and exchange markets and as a loss of confidence on the part of international investors (Corden 1999), as a problem of weak financial institutions (Jackson 1999) and as a problem of policies (Montes 1998). Most of these analyses are themselves written from within the framework of assumptions of the very economic system that itself caused the crisis. As a result many of these (often virtually instant) analyses are partial and theoretically flawed.

This paper will attempt to re-read the 'crisis' and the post-crisis societies of Southeast Asia from a sociological and theoretical viewpoint in an attempt to ask more searching questions about what the 1997 crisis 'means' when it comes to conceptualizing or reconceptualizing processes of social transformation in contemporary Southeast Asia beyond the conventional paradigms that have tended to dominate interpretation hitherto. The paper in other words is a theoretical one that does not purport to add new data, but wishes rather to pose the question of the interpretation of the crisis from a sociological rather than from an economic angle. Here there are two key issues: what a sociological reading of the crisis might look like, and how this might contribute to our understanding of patterns of social change in turn of the century Southeast Asia on the one hand, and on the other what the study of the sociology of Southeast Asian transformations might contribute to broader sociological theory, in which Southeast Asia is not seen simply as a case study but as the source of input into much wider debates in sociology in general and the sociology of development in particular.

The origins of the economic meltdown that began in Thailand and spread rapidly throughout the rest of the region with particularly dire effects in Indonesia, serious effects in Malaysia and significant 
but less damaging consequences in Singapore, Brunei and the Philippines, has been attributed to a number of factors. Amongst the longer term background factors were weak financial institutions, corruption, manipulation of regional economies by local elites (crony capitalism in other words), weak fundamentals ('growth' in some cases, as in Japan, being attributable to rapidly inflating real estate values, the selling off of assets to foreign investors or the export of non-renewable resources, rather than to the development of real productive forces) and the illadvised restructuring of regional economies along lines dictated by the International Monetary Fund and the World Bank, advice which had previously done immense damage to the Mexican economy and shortly after the Asian crisis led to the virtual collapse of Argentina, another hollow economy that had been touted as a Latin American success story parallel to that of the 'little dragons' of Southeast and East Asia. The immediate cause has been seen as the sudden huge fluctuations in capital flows and deliberate currency manipulations of international financiers and currency traders. Underlying sociological fundamentals have however received little attention.

In fact the crisis of 1997 and its subsequent social fallout have highlighted three major dimensions of the social forces underlying Southeast Asia's collective social transformation. The first of these is the depth of the penetration of globalization into the regional societies. The extensive theoretical and ideological literature on globalization often fails to examine its concrete manifestations in particular places or the full range of its effects, which in practice include the sociological and the cultural as well as the 'purely' economic, a category that in fact does not exist. The full range of these effects however was made starkly visible in post-1997 Southeast Asia (Yamashita and Eades 2003). The second is the question of the real success of 'development'. After years and in some cases decades of high levels of economic growth fuelled by the very forces that engineered the subsequent collapse, the crisis demonstrated the hollowness of development built upon volatile and amoral capitalist/globalized foundations and its absolute dependency on those foundations. The conventional argument that the crisis wiped out or set back a decade at least of development (especially in areas such as poverty eradication) is only partly true. The case rather is that this 'development' was arguably a chimera that was inherently unsustainable. What the crisis demonstrated from a more radical viewpoint was not an unfortunate regression, but much more fundamentally the limits of 'development' as it has been largely pursued by the developmentalist states 
of Southeast Asia in the last three decades, and the environmental and socio-cultural consequences and uncontrolled transformations promoted by this economism based largely on some local varieties of neo-liberal thinking combined with the soft authoritarianism so characteristic of regional political cultures. The third, and from the perspective of this paper the most important, is that Southeast Asian social structures were not just 'damaged' by the crisis, but were implicated in it from the beginning, or at least certain class factions were. Those classes (a minority in much of the region) that have benefited from the globalized capitalism that has certainly transformed their societies have, by pursuing a social restructuring that has encouraged consumerism, the motor-car, hyperurbanization, individualism, secularization, McDonaldization and the Hollywoodization that have undermined local cultural integrity and autonomy, created precisely the kinds of social conditions most easily shaped by globalized capitalism and hence most vulnerable to its vagaries and its comings and (as the crisis epitomized) goings.

The question then becomes, what are the sociological aspects of Southeast Asian capitalist societies (clearly a different argument would be necessary in relation to the socialist or post-socialist states of Vietnam, Laos and Cambodia, and for different reasons for Myanmar) that the crisis highlights and which are implicated in it? Identifying these has substantial implications for development sociology generally. The first of these I will argue is class, a notion not widely used in the sociological analysis of the ASEAN countries (probably because of its Marxist and ideological connotations), although the term 'social stratification' is widely used (e.g. Ko 2002). I have recently argued elsewhere (Clammer 2003a) that class is still a salient category of sociological analysis in Southeast Asia and that the failure of analysts to name the crisis for what it is - a crisis not of but brought about by a fully functioning international capitalist system - points to the occlusion of this category that once again needs to be brought out into the open. In that earlier paper I argued both that class is a pervasive structuring factor in contemporary Southeast Asian societies, and that it is a paradoxical phenomenon in that the very (upper/middle) class factions that are most active in promoting globalization, consumption and civil society are those with least in common with those (lower/working) class factions that they purport to serve through their involvement in social movements and their desire for access to an expanding social infrastructure. Class factions (including new ones) are not only generated by and subsequently 'effected' by economic transformations, but also actively contribute to them and may 
indeed even benefit from what is certainly experienced as a crisis by the underclass. Other factions however may be badly damaged by the very forces to which they have, quite literally, hitched their fortunes, and both dimensions of this class impact can be seen as the crisis differentially effected social categories within the same countries, depending largely on their concrete relationship to or dependence on globalization.

The sudden burgeoning of studies of the so-called new middle classes almost a decade ago is symptomatic of this (Robison and Goodman 1996). This class was both a product of and an active promoter of the kinds of economic forces that had brought them into being. What those piecemeal studies indicated was the need for a more systematic theorizing of the larger context in which such emergent social elements appear - that is to say the nexus between class, state, globalization and development. While all these terms retain an analytical value, the new configurations of the relationships between them post-1997 need to be mapped out and related in turn to other new social forces in the region (especially religion, new social movements and civil society and changing notions of citizenship). When this is done it will be possible to return again to these concepts, possibly to redefine them, and certainly to rethink their contemporary utility.

But while I am arguing here for the salience of class analysis in understanding the sociological impact of the crisis and equally importantly the differential relationship of different class factions to it, class is not the only relevant sociological parameter. It is a good starting point because my argument here is that the crisis uncovered actual class alliances and interests that had been suppressed in the high growth years preceeding the meltdown. This is significant because it shows the hollowness of much recent talk in the region of the 'recovery' from the crisis. This talk represents an attempt at the normalization of a situation that has in fact revealed social divisions and gross inequalities that still exist even though they may be once again submerged at the level of discourse. This is also to point up once again that this paper is about discourse and the ideological constructions of social 'reality', the 1997 crisis being the most revealing recent event in Southeast Asia for illuminating this process at work.

Class analysis also makes it possible to explore new configurations of ethnic relations that have been emerging as an aspect of social change in the region. The explosion of ethnic or ethno-religious conflict in many parts of the region in the immediate past (in Indonesia, southern Thailand, Myanmar, the southern Philippines) has complex causes. One of the major ones has been the ways in which national govern- 
ments, committed to a statist model of political organization that has been one of the outcomes of the institutional convergence promoted by globalization and modernity and intensified by the socio-cultural normalizing tendencies of capitalism and consumption, have attempted to assimilate minorities not only to a common centralized political state, but also to an integration into the developmentalist model (Bertrand 2004; Duncan 2004). In other words, I am suggesting that while many regional explanations of ethnic conflict have taken a conventional view based on ideas of race and of centre-periphery tensions, the 1997 crisis in fact reveals both the extent to which ethnicity and class have become entangled and often reflections of each other, and the extent to which the de facto pursuit of a common commodified culture and the social relations implied by such a culture (the nuclearization of the family, monogamy and so forth) has promoted resistance to this homogenization. This resistance then comes to be reflected through one of the only available channels available to many agents, notably ethnicity, this being the only socio-political vocabulary available to them. While from the actor point of view this is entirely understandable, here I am arguing that, from a structural or macroscopic viewpoint, in fact both class and ethnicity are encapsulated in a larger and different framework of commoditization, and that a fresh sociological language is needed regionally to talk about this new configuration implicitly highlighted by the events of 1997, although they were clearly existent long before the crisis to which they were in fact a contributing factor.

The relationship between class/ethnicity and the patterns of resistance to and incorporation in the transformations of culture engineered by politically led developmentalism that began to emerge in the 1970s came to fruition in the 1990s, and were both revealed and implicated in the social basis of the events of 1997 (Zawawi 1998). As De Koninck persuasively argues, for example, one of the major effects of agricultural modernization in Malaysia has been the displacement of many of the rural poor from the productive process altogether, while the mechanization of agriculture has in particular marginalized women who are increasingly excluded from work and are consequently forced into unemployment, or for the younger women into migration to cities into domestic labour or factory work in the export-processing zones of Penang or even as far afield as Singapore (De Koninck 1992). Combined with this kind of major shift in the composition and geography of the labour force (and examples can be multiplied for Indonesia and Thailand in particular) has been the parallel but mostly ignored growth of 
consumerism and the radical life-style and cultural changes that this has brought about (Chua 2000). These in turn have substantial effects on gender relations which of course in turn influence patterns of the household consumption, child socialization and subjectivities of all the actors involved, many of which no longer fit older anthropological assumptions about the ways in which gender and family relationships are structured in Southeast Asia (Stivens 1991; Karim 1995).

The political/economic structures that had been set in place before the crisis and which made it sociologically difficult to resist have had fundamentally transformative effects across the region, influencing class, ethnicity, gender, lifestyles, subjectivities, rural-urban relationships, labour-force composition and distribution, property relations, spatial patterns and rights and freedoms (Scott 1998). Far from being a purely financial crisis, the events of 1997 signaled major sociological shifts in Southeast Asia that had not been fully noted, pointed up the complicity in the events of certain social strata in the region and suggest radical revisions in the sociology of development, which is shown to have been asking many of the wrong questions as a result of clinging to an outmoded paradigm of the forces that shape the social make-up of the region.

\section{Class, State and Crisis}

The 1997 crisis was for Southeast Asia the equivalent of the fall of the Berlin Wall in Europe almost exactly a decade before. The crisis has confounded many of the rosy expectations about the permanent growth and stability of the Asia-Pacific region. Almost nowhere has it occasioned a rethinking of sociological fundamentals and of the long term consequences of continuing to attempt to pursue the same path, except amongst many of the regional social movements and a few of the public intellectuals associated with them (e.g. Camilleri and Muzaffar 1998), whose work tends not to spill over into academic discourse.

A new road map of contemporary sociological configurations is, as suggested above, urgently needed, the outlines of which are futher developed below, pointing to the elements of an alternative model. The assumptions of economic dynamism and political stability touted by many commentators on the region have now to be closely questioned and deconstructed. What emerges instead is a sorry picture of weak states, many of them with a political culture of either authoritarianism and corruption, or both, either unable to devise regulatory mechanisms to protect their own people from the worst ravages of globalization, or riven by factionalism in which domestic special interest elites were able 
to prevent the passage of legislation or regulations which would have benefited the bulk of their populations when those regulations might have damaged the financial interests of those elites (e.g. MacIntyre 1999). Moreover, those governments which followed IMF instructions (most notably Indonesia) fell even deeper into crisis and recession, suggesting that most regional governments exist for the sake of international capitalism and the world order framed by the three dominant international pro-globalization bodies - the IMF, World Bank and the WTO - rather than for the bulk of their often impoverished populations. The class interests of local elites most closely aligned with the world view of neo-liberal economics were consistently allowed to take precedence over the well being or long term future of the average citizen. The very representation of the crisis as a financial one itself indicates how it has been constructed drawing attention away from the underlying sociological realities. This representation requires deconstruction before any movement towards reconstruction of our understanding of social transformations in Southeast Asia.

But before returning to the sociology, a number of background factors that are deeply implicated in the genesis of the crisis and which constitute the frame into which the sociological factors must be fitted need to be identified more fully. Firstly, economic globalization turns out to mean not only the interdependency of economies linked by fair patterns of trade, but also the massive self-interested control exercised by international capital and particularly the unrestrained flows of liquid capital and the manipulation of exchange rates, suggesting that the analysis of many critics of globalization (e.g. Greider 1997) are essentially correct in their view that capitalist economics is now the dominating force in the structuring of societies, and that it remakes societies in its own image, regardless of the costs in terms of cultural erosion and the relentless reconfiguration of what Goran Hyden, speaking of Africa, has called 'economies of affection' into economies of greed, consumption, profit and competition (Hyden 1980).

Secondly, we see actual if not formal loss of sovereignty on the parts of regional governments to economic managers of private foreign companies and to the multilateral institutions. While nation-statesare certainly not in any immediate danger of disappearing this is not because they remain powerful, but because they are useful agents of globalized capital. The most superficial investigation of any state in the region indicates quite clearly that politics now means basically the management of the economy and that calls for the recognition of cul- 
ture and values in development are in reality for the most part shunted aside in the pursuit of growth (Clammer 1996). The weakness of local political, social and cultural integrity in the face of globalization and under the banner of 'development' was clearly revealed during and after 1997. The state in Southeast Asia has largely become a regulatory state with a diminishing agency of its own as it is itself embedded in a globalized environment. The state is needed because it promotes or protects capital, not because it defends its citizens against the worst excesses of capital: it takes on what Immanuel Wallerstein has aptly called the 'night watchman' role, a far cry from its once touted function as the promoter of liberty, equality and fraternity. Amartya Sen's (1999) much discussed notion of development as freedom in reality takes on a meaning that I doubt that its author intended - the freedom to consume, to have one's culture transformed and to see one's social structure rearranged. Indeed it has been the transformation of Southeast Asian societies in the direction of becoming consumer societies that marks one of the most fundamental shifts in socio-cultural organization since the demise of colonialism (Clammer 2003b) While regional states may indeed be autonomous vis-à-vis their local labour, environmental and other social movements, they are accountable ultimately not to their electorates, but to international capital and the multilaterals. The traditional political science conception of sovereignty, frequently invoked by regional states against their critics, evidently needs fundamental rethinking in the light of the real world that 1997 has so starkly revealed.

It is evident that the crisis showed the fallacy of basing development on foreign-finance-led growth. While the situation varies from country to country (with Indonesia being the worse effected) significant increases in poverty, malnutrition and unemployment were registered across the region. What has not been publicised are the knock-on effects of these on gender relations, morale and psychological stability, access to educational opportunities and the housing market, and purchasing power for domestic as well as imported products. While export-oriented companies may have benefited from the sharply declining values of their local currencies (Hill 1999: 6) this is not good news for the rest of the population, as other societies such as Mexico and Argentina have also found as a result of 'liberalizing' their economies and following IMF prescriptions. In such circumstances the urbanization of much of the region proves to be a liability, for while agricultural incomes, being less exposed to what Hill blandly calls the 'modern financial system', were 
less effected by the crisis or even benefited from currency depreciations, the urban poor were very hard hit and have not recovered.

Unwillingness on the part of economists linked to the World Bank to recognize any sociological or political dimensions to the crisis has led some such people to argue, quite fantastically, that 'a large negative shock to confidence and a weak financial sector rather than deep fundamental flaws across the crisis economies can explain much of the onset of the crisis' (McKibbin 1999: 126). More informed analysis of the region, alert to the underlying problematics of mal-development, lack of serious attention to poverty alleviation, uncontrolled urbanization (itself led by real-estate 'developers'), AIDS, widespread ecological degredation, proletarianization of the work force and the erosion of the agricultural sector, has come to radically different conclusions. Indeed in the country in which the crisis began (Thailand) all these features of 'development' and more (including unregulated international tourism) were in place as the 'crisis' broke. In fact there was already a crisis, but one unnoticed by the international press as it was not a 'financial' one that threatened to spread to the rest of Asia and possibly the rest of the world (Bello, Cunningham and Li 1998). This silent crisis includes widening social inequalities, religious violence, the massive spread of HIV/ AIDS, uncontrolled urbanization, local resource depletion (including forests and natural gas), rising crime, child labour, abuses of human rights, serious environmental pollution falling on everybody but especially on the poor, cultural erosion, a spreading drug culture and massive shifts in gender and other social relationships. This is the real crisis and it was there before 1997, was in large part created by the very forces that engineered the financial meltdown and will remain unaddressed by the post 1997 attempts to return things to 'normal'.

The question must consequently be raised as to what extent colonialism is really over in Southeast Asia and to what extent new forms of domination have simply replaced the older forms of direct foreign rule. While the case can certainly be made (as it was in outline above) that globalization has led to the decline of effective national sovereignty, two further points need also to be made. The first is the extent to which the nationalism which succeeded formal colonialism was itself in the interests of the mass of the local populations, or was in fact the replacement of foreign elites with domestic ones, which continued in practice many of the policies of the colonial era. Nationalism and democratization are not synonymous, and the pervasive authoritarianism, militarism and corruption of many regional political regimes, combined with indebted- 
ness to the IMF and WB, the encouragement of foreign direct investment and often subservience of foreign policy to powerful outside interests (the United States in particular) have meant that talk of national 'autonomy' is hollow.

The second point relates to culture and the extent to which globalization has not only meant the erasure of effective national economic autonomy, but also implies the erosion of autonomous local cultures and the increasing globalization of social structures, which come to resemble each other more and more. The emergence of the 'new middle classes' and their common consumption patterns is a prime example of this. While the loss of national sovereignty is seen by some as being the main problem, I would wish to modify this by arguing firstly that the crisis indicates that the nation may not be the best unit to protect and enhance the interests of the majority population of a given area, being frequently if not always riddled with class and elite interests (something thrown into high relief by the crisis) as well as the interests of dominant ethnic groups. It is quite easy to buy off the working class for example through the expansion of consumption without fundamentally transforming their actual conditions of labour. Secondly, the globalization of social structures and cultural practices is as serious a problem as economic globalization (Tomlinson 1999). In fact the two are intimately linked, as the penetration of consumerism and the spread of what Robert Heffner and collaborators call 'market cultures' (in which issues of morality and society are closely tied to economic transformations in the new Asian capitalisms) indicate that forms of capitalist culture have become the everyday cultural reality for virtually everybody in the region (Heffner 1998). What the crisis has highlighted is the power of this nexus and the consequent lack of cultural and sociological resources to withstand the effects of that crisis or to modify the form and definition of 'development' that it has created and actively promotes. Talk of 'Asian capitalisms', as if they were somehow more benign than their Western originating models, simply obscures the local forms of social transformation imposed by the market, intensified by the fact that these capitalisms are, in a semi-dependent way, integrated into a total world-system the nature and functioning of which they do not and cannot determine (Wee 2002).

The editors of a relatively recent volume of critical essays on Southeast Asian development (Dragsbaek-Schmidt, Hersh and Fold 1998: 1), the publication of the original 1997 edition of which coincided exactly with the timing of the crisis, argue, rightly in my view, that it is misleading 
to make what they call an 'artificial division between state and market' in seeking an accurate analysis of the actual agents of social change in Southeast Asia and the emerging structures of unequal distribution of social, political and material rewards, in which the class paradigm must continue to play an important role as new forms of ('Asian') capitalism emerge and as the advanced capitalist economies export more of their offshore production to the cheaper labour markets of Southeast Asia. In such a context, even though the concept of class itself has become somewhat elastic, as Dragsbaek-Schmidt and collaborators argue 'it is difficult if not impossible to grasp in any meaningful way the economic and social contradictions between strata and social groupings without reconsidering the concept of class' (ibid.: 2). This is because as processes of production change and economies create wage-labour and a bourgeoisie, owners and workers, and as labour becomes a commodity, so social relations between the elements in a society also change. The continuing and indeed intensifying social relations between 'producers and appropriators of surplus labour' (ibid.: 2) make class not a less salient category in Southeast Asia, but one of increasing significance, as I have suggested earlier. With so much attention having been given and continuing to be given to ethnicity in Southeast Asia as the major category for exploring social differentiation, the crisis strongly suggests that we once again direct attention to class, but also to the connections between class and ethnicity.

These classes (both old and emergent) are themselves a product of the economic transformations of Southeast Asia since 1945. The varieties of local colonialism had of course also introduced new forms of stratification into what, it must be remembered, were already highly stratified societies. New forms of agricultural practice (plantations and agribusinesses) and export-oriented manufacturing, together with the subsequent growth of services, bureaucracy and the military made possible by the rising surplus, lead naturally to new social categories, the interests of which may certainly not be identical and which may be further internally segmented and may have very different internal cultures and consumption patterns. What the 1997 crisis has highlighted is the presence of this social differentiation and the very different corresponding relations to the world system on the part of the different social strata, some of whom continue to benefit from it even under conditions of crisis and others who have rapidly been devoured by it. Conflicts and alliances between these strata that were largely latent pre-1997, when a common language of growth and development tended to submerge 
actual social differences, have become clear as a result of the crisis, as has been true in other Asian societies such as Japan with the collapse there of the 'bubble economy' that began to deflate around 1996 and might even be causally related to the 1997 Southeast Asian collapse.

Class, then, continues to be a central sociological category for the understanding of contemporary Southeast Asian societies. It throws into relief both the social differentiation of regional societies and the ways in which some of these have been intensified and revealed in stark ways by the sociological fallout from the crisis. Externally the Southeast Asian economies are dependent and internally this dependency is strengthened by the presence of (middle and capitalist bourgeoisie) classes wholly reliant on the continuation of this path and as such working in close tandem with the political-bureaucratic strata (McVey 1992). The result of such elite policy making has been what DragsbaekSchmidt terms 'growth without welfare' (Dragsbaek-Schmidt 1998: 40) or what slightly earlier was being termed 'uneven development' (Jomo 1988). That 'unevenness' has proved to be not merely potholes in the road, but the absence of a road at all, or at least of one constructed out of sustainable local materials. This requires close engagement with the position of commentators such as Jonathan Rigg, who wishes to have his cake and eat it by arguing both that development has had 'very real failures and inconsistencies' which he lists as 'widening human and regional inequalities, severe environmental problems, the exclusion from development of certain groups in society, and cronyism and corruption, for example', and that the growth/modernization model works (Rigg 1997: 286). This inconsistent position should alert us both to the failure of much academic commentary to name the real problems and the ideological investment that many scholars who like to pose as critical in fact have in the continuation of the very development process that produced the crisis in the first place.

\section{Reconceptualizations After the Crisis}

Up until this point this essay has been one essentially concerned with naming what I would argue is the true nature of the 'crisis': not as a mere financial distortion of an otherwise smoothly functioning system, but as a crisis of (a) globalization, (b) 'development', (c) regional political systems, the inefficiency and class-bias of which has been clearly exposed, and (d) sociological convergence or complicity of social strata themselves created by the very system that engineered the crisis itself and who are now so enmeshed in that system that they are dependent upon it for their own 
future. But what does this point to? What lessons for sociology in general and the sociology of development in particular might be derived from this as they might apply to contemporary Southeast Asia?

Firstly, new forms of Southeast Asian cultural politics are emerging from the recognition that even local cultures are connected to the global. This can lead to new conceptions of citizenship, which, while no doubt still rooted in the individual nation-states, come to take on both a regional and a global aspect as well. While 'culture and development' theorists (e.g. Schech and Haggis 2000) have argued that culture needs to be put back into the (economistic) understanding of development, the stronger thesis is being advanced here that culture is development. The crisis has highlighted the theoretical poverty of a conception of development built on purely economistic assumptions that turn out to erode or destroy the very cultures of the people who are supposed to benefit from that development. Even the provision of schools and healthcare is of little meaning if the real intention is to turn children into middle class consumers and to keep their bodies fit for capitalist labour and military service. Some commentators who have argued, rightly I think, for the centrality of cultural analysis in the understanding of Southeast Asian societies (e.g. Kahn 1998a) have gone as far as to suggest that in reality Southeast Asia is in a post-nationalist phase, not only because of the effects of economic globalization, but also because of (a) the cultural and political linkages that now tie the regional societies to each other and to international civil society organizations, social movements and religions, (b) the widespread access to information technology and (c) the increasingly common language of human rights. By focusing attention on financial concerns the crisis has been constructed in exceedingly narrow terms when in fact it involves not only states, but supra-state actors (international capital and the multilateral institutions that protect its interests in the guise of promoting development and fair trade and which have as a consequence profound sociological effects), and subnational actors (actual local cultures). What links them is the ways in which identities are constructed and reconstructed not any longer out of indigenous local soils, but out of the forces of globalized capitalism that are now the major and almost only source of 'culture' (Reynolds 1998), despite the attempts of regional social movements and NGOs, religious leaders and intellectuals to redefine socio-cultural reality in more nativist terms (Sulak 1985).

Secondly, to focus only on the 'effects' of the crisis is to normalize its true nature and the conditions which allowed it to occur. To do this 
is not only to fail to name the actual factors involved, but is also the failure to understand the underlying social conditions - the remaking and transformation of regional societies in forms that far exceed the wildest excesses of colonialism and is ultimately far less beneficial. The crisis has been constructed in a certain way, and consequently needs systematic deconstruction.

Thirdly, an attractive way of looking at indigenous resources for social change is to turn to the 'new social movements' in the region. But as Dragsbaek-Schmidt (1998: 11) points out, the tendency is to locate these within the sphere of 'civil society' rather than of property relations. In fact, as was noted above, civil society in the region is closely linked to class structures and many civil society organizations are the middle classes organizing to defend their own interests rather than intending to transform their societies. A culturalist emphasis on cultural differentiation (and Southeast Asian Studies has a whole vocabulary for this - plural societies, multiracialism, 'Instant Asia', 'Malaysia, Truly Asia', unity within diversity), while rightly identifying the cultural diversity and richness of the region, fails to make the connection between culture and class and the systemic inequalities that the notion of culture can hide (Kahn 1998b). This is not of course to deny the centrality of culture in class analysis (which this paper is in part intended to restore) or to argue (as Jonathan Rigg does for example) that the new social movements are not important vehicles for social change and for the generation of new thinking about development and values. Rather it is to argue for a new conception of what used to be called political economy in which the economic and the social are analysed together and in their mutual interconnections in a holistic model of social processes and of global-local ones.

As James Goodman has argued at length (Goodman 2003), the shifting impact of neo-liberal globalism has radically altered what he terms the 'mobilization framework' of social movements in Southeast Asia. The weakening of the national development projects of the past decades, new or sharper sub-national or cross national inequalities, and an altered international environment in which transnational capitalism, multilateral institutions and globalization are the key factors or actors, have changed the environment of social mobilization movements throughout the region. The collapse of socialism in all but name in Indochina has similarly contributed to new regional configurations. What 1997 has sharply revealed however is the massive disruption of developmentalism and of the forms of political legitimacy that regional governments attempted to generate for themselves by the single-minded pursuit of 
that agenda. While the destabilization that the crisis revealed (rather than created) has changed the basis of mobilization for older style social movements, it has of course also created new openings. 'Crises delegitimize the status quo, destabilize elite patronage and politicize social life' (Goodman 2003; 34) and potentially at least create a new 'democratic moment' (Acharya 1998) in the political cultures of the regional societies. But even Goodman in his analysis of the impacts of neo-liberal globalization on Southeast Asia persists is seeing the 1997 crisis as a financial one, even though his own argument points to much wider implications and causes, the deepening inequalities that are the focus of his essay being the main symptoms of this. It is precisely to cover up this underlying truth that so much effort has been expended on constructing the 1997 crisis as a financial one. The real crisis is far wider, deeper and more fundamental, but the recognition of this would of course force some equally fundamental political and policy changes that are profoundly unpalatable to the governments of the region, the multilaterals and the corporate interests which themselves are driving the globalization that is at the root of the crisis.

The crisis has of course had its 'effects' - on poverty alleviation, employment, housing, education, provision of health care and gender relations. These effects, however, while they have certainly damaged the new middle classes as the stratum most closely identified with the dependent development that has created the crisis, have fallen most heavily on the already disadvantaged and on the poor in particular. The construction of the crisis as essentially a financial problem pointing up the weakness of regulatory regimes in Southeast Asia has entirely missed this point. It has also failed to take into account the long term sustainability of the dependent development that the region's governments are committed to - in particular environmental impact, resource depletion and long term energy issues. In their rush to build new airports or to add new terminals to already half empty ones, governments appear to be paying little attention (although the West's incursions into Iraq may suggest another interpretation) to the well-documented expectations that known oil reserves will be largely exhausted by 2030 (Mason 2003; Rifkin 2003). It may well be that the history of the region will ensure that the poor and marginalized will get their revenge and that within many of our lifetimes it may be the peasants and hunter-gatherers of Southeast Asia's forests who (re)inherit the earth.

What has happened in the region has been fast capitalist economic growth outstripping the development of political institutions and 
processes. Authoritarianism, weak democratic institutions, electoral manipulation, corruption, controlled media, a dependent judiciary and an underdeveloped civil society (Johannen, Rudolph and Gomez 2000: 8) have provided exactly the conditions for the penetration of unrestrained capitalism, have excluded the articulation of political and social alternatives and have fundamentally weakened the ability of individual nation-state actors in the region to respond to the pressures of globalization, even if they wanted to. So far I entirely agree (that one major and neglected factor in the genesis of the crisis is governance) but where I depart from this analysis is the assumption that existing capitalism is the only system available to the societies of Southeast Asia, or as Rudolph puts it 'successful market economies require political freedom to provide a barrier against economic cronyism and other anti competitive and inefficient practices' (ibid.: 13). For here we have a critique that shares the basic assumptions of the engineers of the crisis: that globalized marketization is inevitable and all that can be done is to improve its working to make it more 'efficient'. In fact there are more moderate positions between slavish acceptance of 'free' market capitalism and the outright rejection of globalization, for example the thesis of George Monbiot that the challenge is not to overthrow globalization but precisely to capture it for democratic, egalitarian and genuinely internationalist progressivism that would allow and indeed encourage international cooperation and the huge benefits of access to one another's cultures while avoiding the equally huge damaging effects of the capitalist/IMF version (Monbiot 2003).

\section{Southeast Asia After 'Modernity'}

Let me conclude by recapitulating my main thesis and briefly suggesting where it points in terms of future analysis and action. I have argued essentially that the 1997 crisis has largely been constructed as a financial problem, caused by weak regulatory bodies and regional governments and to be solved or prevented from happening again by more and stronger regulations, largely imposed from the outside by the IMF. I have suggested that this analysis is fundamentally wrong and theoretically impoverished, not least because it ignores the sociological factors at work throughout the region that have silently transformed Southeast Asia into one of the foremost areas of the world in which capitalist production relations and their social and cultural consequences have been given the freest rein under the labels of developmentalism and modernization. Accordingly I have advanced 
the argument that the crisis is an outcome of both globalization and a false conception of development and represents a profound form of neo-colonialism masquerading as modernity, a point developed at length by Zygmunt Bauman (1999), who has argued that in the West the outcome of modernity was not emancipation, but the Holocaust; in Southeast Asia the outcome has been 1997. Underlying and largely concealed by this globalization have been new social patterns that have emerged in Southeast Asia in the past three decades or so, many of which have not been fully mapped or identified, but which I have argued provided the social context in which a crisis could so easily erupt. The real nature of this historical process can be seen not only in its ecological unsustainability, but sociologically in its effects on class formation and social differentiation, and its remaking of regional cultures as consumer cultures which are, by virtue of becoming part of the 'inside' of global capitalism, unable to resist that globalization or in extreme cases even to conceptualize alternatives to the 'reality' in which they find themselves.

This has a number of implications for the analysis of Southeast Asian societies. Firstly, while by no means unimportant, social movements and civil society organizations can have little fundamental effect on positive social transformation unless they are both aware of and can detach themselves at least to some degree from this hegemonic discourse and practice. Secondly, while the examination of culture is equally important, it cannot be separated from class analysis, the generation and expression of culture being itself in part a function of class position as Pierre Bourdieu has demonstrated for European societies (Bourdieu 1984). Thirdly, a more accurate understanding of the fundamental nature of the crisis allows engagement with many of the ideological obfuscations that in the past have clouded the determination of the actual relationships between rapid capitalist-led economic growth, authoritarian government and lack of deep democratization, such as the so-called 'Asian Values' debates and their connection with limited support for human rights and suppression of a free media (Jacobsen and Bruun 2000), and fundamental sociological shifts, often unnoticed for some time because of the persistence of older categories of social analysis such as the use of plural society models and the privileging of ethnicity over class. An accurate understanding of the nature of the crisis permits constructive debate on alternative futures, other conceptions of development and relationships between peoples and governments. As David Harvey has so cogently argued, contemporary globalization and the deeply unequal geographical development that it 
has promoted - a whole geography of inequality - have historical roots and hence are contingent not necessary (Harvey 2000).

Furthermore, deeply implicated in patterns of economic change are the parallel changes in culture, subjectivities, morality and identity that accompany the transformations that Southeast Asia has experienced in the last three decades. If in modern history colonialism was the first such seismic shift and decolonization the second, it has undoubtedly been the absorbtion of the region into the international capitalist system that has been the third. Many of the socio-cultural effects of this were occluded until the 1997 crisis threw them into stark relief and called into question the whole notion of 'miracle economies', so celebrated by the adherents of neo-liberalism and the Washington Consensus (Jomo 2003). If the crisis is simply normalized and business-as-usual continues, the lessons of 1997 will not have been learnt and the next Asian crisis will be even bigger and less manageable. Its positive effects if correctly read will be to lead to the development of a new paradigm for Southeast Asian Studies. This paradigm (a) will bring together the analysis of the economic and the social, (b) will be alert to the quiet but fundamental shifts in sociology and subjectivity and the subtle cultural expressions of class that have accompanied economic transformations, (c) will situate Southeast Asia within the larger framework of globalization, and (d) will build on the possible gains of the crisis. These can be (a) a strengthened labour movement and movements for increased democratic and electoral participation and the corresponding visibility of arguments for human and environmentally responsible development (Malhotra 2002), (b) the weakening of developmental authoritarianism as its credibility has collapsed, and (c) the resisting of issues of values at the centre of debates about the meaning of development in a region where religious affiliation and commitment to traditional forms still remains strong. Cultural conflicts will then appear as what they often are - the outcome of unresolvable tensions between the culture of the state and the culture of the as yet half-digested culture of the market and of consumption, expressed in the language of ethnicity, but in fact the leading symptom of the vast socio-cultural shifts that Southeast Asia has experienced in its recent postcolonial history and of which the crisis of 1997 was the most dramatic, but by no means the last, expression.

John Clammer is Professor of Comparative Sociology and Asian Studies at Sophia University, Tokyo. 


\section{REFERENCES}

Acharya, A. 1998. Democratizing Southeast Asia: Economic Crisis and Political Change. Perth: Murdoch University, Asia Research Centre. Working Paper No. 87.

Arndt, H.W. and H. Hill (eds) 1999. Southeast Asia's Economic Crisis: Origins, Lessons and the Way Forward. Singapore: Institute of Southeast Asian Studies.

Bauman, Zygmunt 1999. Modernity and the Holocaust. Cambridge: Polity.

Bello, W., S. Cunningham and K.P. Li 1998. A Siamese Tragedy: Development and Disintegration in Modern Thailand. London and New York: Zed Books.

Bertrand, J. 2004. Nationalism and Ethnic Conflict in Indonesia. Cambridge: Cambridge University Press.

Bourdieu, P. 1984. Distinction: A Social Critique of the Judgement of Taste. Cambridge, MA: Harvard University Press.

Camilleri, J.A. and Chandra Muzaffar (eds) 1998. Globalisation: The Perspectives and Experiences of the Religious Traditions of Asia Pacific. Petaling Jaya: International Movement for a Just World.

Clammer, J. 1996. Values and Development in Southeast Asia. Petaling Jaya: Pelanduk.

-2003a. 'Globalization, Class, Consumption and Civil Society in Southeast Asian Cities'. Urban Studies 40 (2): 403-419.

-2003b. 'Culture and Consumption in the Post-Industrial City'. In F. Eckardt and D. Hassenpflug (eds) Culture and Consumption in the Post-Industrial City. Frankfurt and New York: Peter Lang: 91-102.

Chua, B.H. (ed.) 2000. Consumption in Asia: Lifestyles and Identities. London: Routledge.

Corden, M. 1999. The Asian Crisis: The Causes and Consequences of a Financial Crisis. Singapore: Institute of Southeast Asian Studies.

De Koninck, R. 1992. Malay Peasants Coping With the World. Singapore: Institute of Southeast Asian Studies.

Dragsbaek-Schmidt, J, J. Hersh and N. Fold (eds) 1998. Social Change in Southeast Asia. Harlow: Addison Wesley Longman.

Dragsbaek-Schmidt, J. 1998. 'The Custodial State and Social Change: Creating Growth Without Welfare'. In J. Dragsbaek-Schmidt, J.J. Hersh and N. Fold (eds) Social Change in Southeast Asia . Harlow: Addison Wesley Longman: 40-59.

Duncan, C.R. (ed.) 2004. Civilizing the Margins: Southeast Asian Government Policies for the Development of Minorities. Ithaca and London: Cornell University Press.

Goodman, J. 2003. 'Contesting the New Inequalities: Social Movements in the Asia Pacific'. In T.J. Scrase, T.J.M. Holden and S. Baum (eds) Globalization, Culture and Inequality in Asia. Melbourne: Trans Pacific Press: 21-47.

Greider, W. 1997. One World Ready or Not: The Manic Logic of Global Capitalism. London: Penguin Books.

Harvey, D. 2000. Spaces of Hope. Edinburgh: Edinburgh University Press.

Heffner, R.W. (ed.) 1998. Market Cultures: Society and Morality in the New Asian Capitalisms. Boulder, CO: Westview Press.

Hill, H. 1999. 'An Overview of the Issues'. In H.W. Arndt and H. Hill (eds) Southeast Asia's Economic Crisis, Singapore: Institute of Southeast Asian Studies: 1-15.

Hyden, G. 1980. Beyond Ujamaa in Tanzania: Underdevelopment and an Uncaptured Peasantry. London: Heineman.

Jackson, K.D. (ed.) 1999. Asian Contagion: The Causes and Consequences of a Financial Crisis. Singapore: Institute of Southeast Asian Studies.

Jacobsen, M. and O. Bruun (eds) 2000. Human Rights and Asian Values: Contesting National Identities and Cultural Representations in Asia. Richmond: Curzon Press. 
Johannen, U., J. Rudolph and J. Gomez (eds) 2000. The Political Dimensions of the Asian Crisis. Singapore: Select Books and the Friedrich Naumann Foundation.

Jomo, K.S. 1988. A Question of Class: Capital, the State and Uneven Development in Malaysia. New York: Monthly Review Press.

Jomo, K.S. (ed.) 2003. Southeast Asian Paper Tigers? From Miracle to Debacle and Beyond. London: RoutledgeCurzon.

Kahn, Joel S. (ed.) 1998a. Southeast Asian Identities: Culture and the Politics of Representation in Indonesia, Malaysia, Singapore and Thailand. Singapore: Institute of Southeast Asian Studies.

-1998b. 'Class, Culture and Malaysian Modernity'. In J. Dragsbaek-Schmidt, J.J. Hersh and N. Fold (eds) Social Change in Southeast Asia. Harlow: Addison Wesley Longman: 81-97.

Karim, W.J. (ed.) 1995. 'Male' and 'Female' in Developing Southeast Asia. Oxford: Berg.

Ko, Y.C. 2002. 'Class and Social Stratification'. In C.K. Tong and K.F. Lian (eds) The Making of Singapore Sociology: Society and State. Singapore: Times Academic Press and Brill: 193- 217.

MacIntyre, A. 1999. 'Political Institutions and the Economic Crisis in Thailand and Indonesia'. In H.W. Arndt and H. Hill (eds) Southeast Asia's Economic Crisis. Singapore: Institute of Southeast Asian Studies: 142-157.

Maidment, R. and C. Mackerras (eds) 1998. Culture and Society in the Asia-Pacific. London and New York: Routledge.

Malhotra, K. 2002. 'Development - Enabler or Disabler? The Role of the State in Southeast Asia'. In C. Wee (ed.) Local Cultures and the 'New' Asia: The State, Culture and Capitalism in Southeast Asia. Singapore: Institute of Southeast Asian Studies: 31-50.

Mason, C. 2003. The 2030 Spike: Countdown to Global Catastrophe. London and Sterling, VA: Earthscan Publications.

McKibbin, Warwich 1999. 'Modelling the Crisis in Asia '. In H.W. Arndt and Hal Hill (eds), Southeast Asian's Economic Crisis: Origins, Lessons, and the Way Forward. Singapore: Institute of Southeast Asian Studies: 119-127.

McVey, R. 1992. 'The Materialization of the Southeast Asian Entrepreneur'. In R. McVey (ed.) Southeast Asian Capitalists. Ithaca, NY: Cornell University Southeast Asia Program.

Monbiot, G. 2003. The Age of Consent: A Manifesto for a New World Order. London: Flamingo.

Montes, Manuel F. 1999. The Currency Crisis in Southeast Asia. Singapore: Institute of Southeast Asian Studies.

Reynolds, C.J. 1998. 'Globalization and Cultural Nationalism in Modern Thailand'. In J.S. Kahn (ed.) Southeast Asian Identities. Singapore: Institute of Southeast Asian Studies: 115-145.

Rifkin, J. 2003. The Hydrogen Economy. New York: Jeremy P. Tarcher/Penguin.

Rigg, Jonathan 1997. Southeast Asia: The Human Landscape of Modernization and Development. London and New York: Routledge.

Robison, R. and D.S.G. Goodman (eds) 1996. The New Rich in Asia: Mobile Phones, McDonalds and Middle Class Revolution. London and New York: Routledge.

Schech, S. and J. Haggis 2000. Culture and Development. Oxford: Blackwell.

Scott, J. 1998. 'Freedom and Freehold: Space, People and State Simplification in Southeast Asia'. In D. Kelly and A. Reid (eds) Asian Freedoms: The Idea of Freedom in East and Southeast Asia. Cambridge; Cambridge University Press: 37-64.

Sen, A. 1999. Development as Freedom. Oxford: Oxford University Press.

Stivens, M. (ed.) 1991. Why Gender Matters in Southeast Asian Politics. Melbourne: Murdoch University Press. 
Sulak, S. 1985. Siamese Resurgence: A Thai Buddhist Voice on Asia and a World of Change. Bangkok: Asian Cultural Forum on Development.

Tomlinson, J. 1999. Globalization and Culture. Cambridge: Polity.

Wee, C. (ed.) 2002. Local Cultures and the 'New' Asia: The State, Culture and Capitalism in Southeast Asia. Singapore: Institute of Southeast Asian Studies.

Yamashita, S. and J. S. Eades (eds) 2003. Globalization in Southeast Asia: Local, National and Transnational Perspectives. Oxford and New York: Berghahn Books.

Zawawi, Ibrahim 1998. The Malay Labourer: By the Window of Capitalism. Singapore: Institute of Southeast Asian Studies. 